J.Lake Sci. (湖泊科学), 2016, 28(1): 9-21

DOI 10. 18307/2016. 0102

(C) 2016 by Journal of Lake Sciences

\title{
太湖流域水库型水源地硅藻水华发生特征及对策分析“
}

\author{
朱广伟 ${ }^{1}$, 金䓉薇 $^{1}$,任 杰 $^{1}$, , 夏明芳 $^{2}$, 许 海 $^{1}$, 朱梦圆 $^{1}$, 费国松 ${ }^{3}$, 陈伟民 ${ }^{1}$ \\ (1: 中国科学院南京地理与湖泊研究所, 南京 210008) \\ (2: 江苏省太湖水污染防治办公室,南京 210013) \\ (3: 江苏省溧阳市水文局,溧阳 213300)
}

\begin{abstract}
摘 要: 基于溧阳市天目湖沙河水库 2009-2014 年的硅藻群落结构及水质调查, 以及宜兴横山水库等硅藻水华期藻类 和水质调查数据, 分析了太湖流域水库中硅藻水华群落结构特征及受气温、水位、营养盐等环境条件的影响. 结果表明, 太 湖流域硅藻水华的主要发生期为 5-7 月, 快速生长期发生在气温为 $16 \sim 26^{\circ} \mathrm{C}$ 期间, 当气温超过 $26^{\circ} \mathrm{C}$ 时, 硅藻的生物量开 始下降. 硅藻的优势属包括针杆藻、曲壳藻、小环藻和颗粒直链藻. 其中沙河水库和横山水库中针杆藻是主要危害, 其生物 量主导了硅藻总生物量. 大溪水库有时以针杆藻为主, 有时以颗粒直链藻为主. 当总氮浓度低于 $1.0 \mathrm{mg} / \mathrm{L}$ 的 III 类水上限 时, 水体氮浓度能大大限制硅藻生物量, 当总磷浓度低于 $0.025 \mathrm{mg} / \mathrm{L}$ 的 II 类水上限时, 也可能对硅藻生物量产生限制. 高 于此营养水平, 硅藻水华的严重程度主要受气温、降雨等因素影响. 研究表明, 对于处于中营养水平的太湖流域水库而言, 硅藻生物量既受气温、降雨、水位等气象水文条件的控制, 又受氮、磷、硅等营养盐供给的影响. 硅藻水华的防控既要关注 气候和气象条件,也要尽量削减氮、磷营养盐入湖通量, 维持较低营养盐水平是确保硅藻水华不形成危害的关键.
\end{abstract}

关键词: 硅藻;水华;水源地;富营养化;气候波动; 天目湖;沙河水库;横山水库;太湖流域

\section{Characteristics of diatom blooms in a reservoir-water supply area and the countermeas- ures in Taihu Basin, China}

ZHU Guangwei ${ }^{1}$, JIN Yingwei $^{1}$, REN Jie ${ }^{1}$, XIA Mingfang ${ }^{2}$, XU Hai ${ }^{1}$, ZHU Mengyuan ${ }^{1}$, FEI Guosong ${ }^{3}$ \& CHEN Weimin ${ }^{1}$

(1: Nanjing Institute of Geography and Limnology, Chinese Academy of Sciences, Nanjing 210008, P.R.China)

(2: Taihu Water Pollution Control Office of Jiangsu Province, Nanjing 210013, P.R.China)

(3: Hydrology Bureau of Liyang, Jiangsu Province, Liyang 213300, P.R.China)

Abstract: Based on monthly investigation of diatom community and the related environmental conditions during six years in Shahe Reservoir, Lake Tianmu, Liyang City, and investigation of the bloom seasons in Hengshan Reservoir, Yixing City, the environmental and biological characteristics of diatom bloom in reservoirs of Taihu Basin has been analyzed. It was shown that the diatom bloom season in these reservoirs normally happened from May to July. The diatom biomass started to increase significantly when air temperature was above $16^{\circ} \mathrm{C}$, and reached the highest growth rate when air temperature was $26^{\circ} \mathrm{C}$. The predominant genera of diatom in these reservoirs were Synedra, Achnanthes, Cyclotella and Melocira. Synedra was the dominant species in the diatom community. Being meso-trophic condition in most of these reservoirs, both climate condition and high nutrient level were important to cause diatom blooms. What total nitrogen is lower than $1.0 \mathrm{mg} / \mathrm{L}$ or total phosphorus is lower than $0.025 \mathrm{mg} / \mathrm{L}$ can create the limitation effect on the diatom biomass in these reservoirs. When the nutrient concentration is higher than those levels, climate condition will be significantly control to make the severity of diatom bloom in the reservoirs.

Keywords: Diatom; bloom; drinking water source; eutrophication; climate fluctuation; Lake Tianmu; Shahe Reservoir; Hengshan Reservoir; Taihu Basin

* 江苏省太湖水环境综合治理科研项目 (TH2014304) 和国家自然科学基金项目 (51279194) 联合资助.2015-03-04 收稿;2015-04-03 收修改稿.朱广伟( 1972 ), 男, 博士, 研究员; E-mail: gwzhu@ niglas.ac.cn. 
水库的有害藻类与浅水湖泊有所不同, 浅水湖泊有害藻类更多地是蓝藻门浮游植物, 而在水库中, 硅藻 是更常见的灾害性水华物种 ${ }^{[1-2]}$. 硅藻属真核生物, 具有较硬的硅质细胞壁, 细胞体积大, 密度大, 相对更适应 于流水环境以及相对冷水的环境, 是海洋赤潮的常见藻类 ${ }^{[3]}$. 在内陆淡水水体中, 常在河流、水库中形成灾害 性水华, 发生季节往往在春季至初夏以及高温之后的秋季 ${ }^{[4]}$. 常见的水华灾害种有小环藻属 $(\text { Cyclotella })^{[5-6]}$ 、

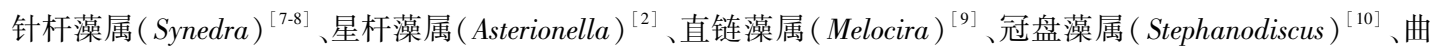
壳藻属 $(\text { Achnanthes })^{[11]}$ 等.

水库型水源地是我国重要的水源地形式, 对于保障城市生活、生产安全用水具有重要的价值 ${ }^{[12]}$. 江苏省 水利厅 2007 年以来分 3 批发布的《江苏省集中式饮用水水源地核准名录》中, 163 个水源地有 40 个是湖库 型水源地, 其中水库型水源地 15 个, 主要分布在太湖流域西部的宁溧镇山脉一带.除了省级水源地外, 太湖 流域的油车水库是宜兴市的第 2 水源地, 溧阳市的前宋水库、团结水库、塘马水库、竹林水库和鸡笼坝水库 也都是溧阳市的市级饮用水源地. 这些水库的水质相对优良, 多年平均水质达 III 级甚至 II 级, 是太湖流域极 其珍贵的饮用水资源 ${ }^{[13]}$.

近年来, 太湖流域的水库型水源地越来越多地受到富营养化问题的困扰 ${ }^{[14-15]}$. 由于太湖流域的人口密度 大, 土地资源少, 所有的水库流域都面临开发强度偏大、面源负荷高的问题 ${ }^{[16-17]}$. 加之太湖流域年均温度高, 降雨丰沛, 藻类的生长期长, 藻类生物量普遍偏高, 存在较大发生藻类水华的风险.

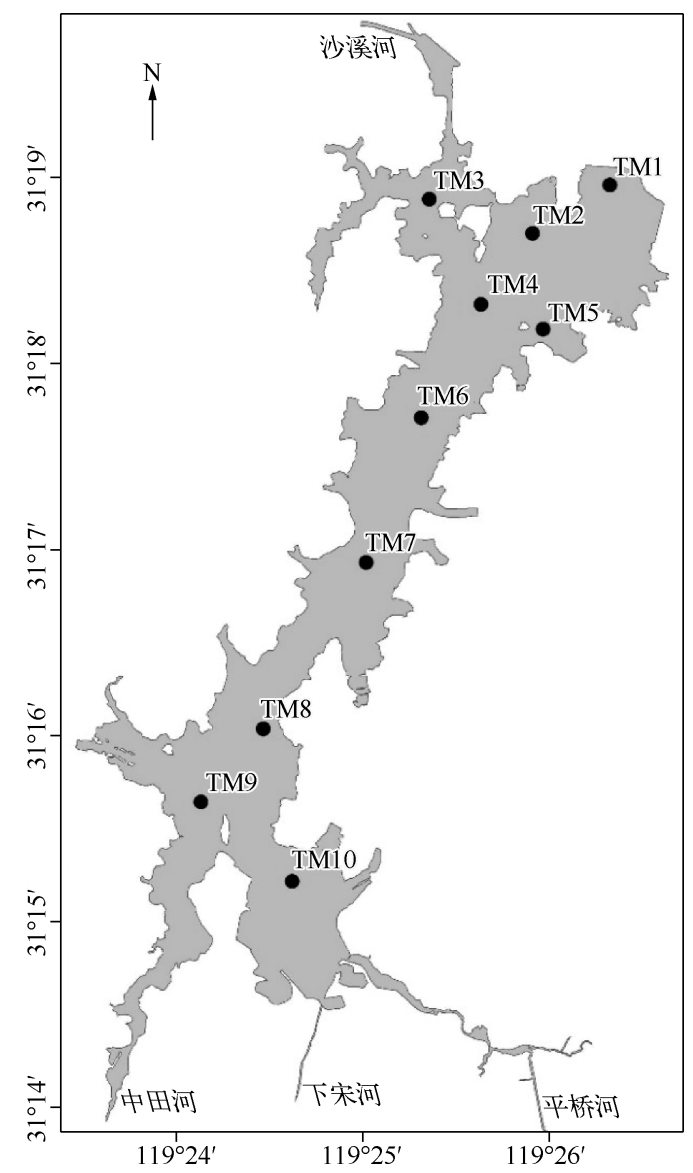

图 1 沙河水库逐月监测点位分布

Fig. 1 Sampling sites for water quality analysis in Shahe Reservoir

为科学应对太湖流域水库型水源地硅藻水华 灾害问题, 本研究基于 2009-2014 年对溧阳市沙 河水库藻类群落结构及相关环境条件的逐月监测, 分析了太湖流域水库型水源地硅藻水华形成的条 件, 并结合天目湖流域水环境保护的工程措施经 验,探讨了太湖流域水库硅藻水华的防控对策.

\section{1 材料与方法}

\section{1 采样点布设}

样品的采集与测定方法参考文献 $[14,18]$. 沙 河水库监测的采样点布设如图 1 所示, 由南向北共 设 10 个采样点, 即上游 3 个点(TM8、TM9、TM10), 中间 4 个点 (TM4、TM5、TM6、TM7), 下游 3 个点 (TM1、TM2、TM3).此外, 为便于比较,在 2014 年 6 月 15 日天目湖相邻的横山水库坝前取水口点位 $\left(31.24^{\circ} \mathrm{N}, 119.57^{\circ} \mathrm{E}\right)$ 进行水质和藻类调查.

\section{2 样品的采集及测定方法}

2009 年共开展了 39 次监测, 春、夏季的监测 频次较高, 2010-2014 年则每月 1 次. 水质与浮游 植物样品采集时均取表层 $0.5 \mathrm{~m}$ 深水样. 溶解氧 (DO) 及水温 (WT) 的剖面监测一般采取 $1 \mathrm{~m}$ 深度 间隔. 现场测定透明度 (SD)、DO、WT 等参数, 采集 $1.5 \mathrm{~L}$ 水样带回室内测定总氮 $(\mathrm{TN})$ 、总磷 $(\mathrm{TP})$ 、叶绿 素 $\mathrm{a}(\mathrm{Chl} . \mathrm{a})$ 浓度等水质指标. 同时采集 $1 \mathrm{~L}$ 水样用 鲁哥试剂固定, 用于浮游植物群落结构的鉴定.

浮游植物群落结构的鉴定使用 Olympus CH 生 物光学显微镜镜检, 鉴定到属, 首先获得细胞密度 ( cells $/ \mathrm{L}$ ), 在各属细胞密度的基础上, 根据体积重量经验公式换算为生物量 $(\mathrm{mg} / \mathrm{L})$, 样品处理和 
测定方法参照文献 $[19]$.

\section{3 数据处理方法}

数据图表绘制及主要统计参数计算均由 Excel 2013 软件完成, 硅藻与环境因子的相关关系用 Pearson 相关系数表达 $(P)$.

\section{2 结果}

\section{1 太湖流域水库硅藻水华的表观特征}

2.1.1 透明度急剧下降 从郑建军等的分析可知,一般细胞密度在 $1 \times 10^{6} \sim 10 \times 10^{6} \mathrm{cells} / \mathrm{L}$ 之间时可认为是轻 度水华, 在 $10 \times 10^{6} \sim 20 \times 10^{6} \mathrm{cells} / \mathrm{L}$ 之间时为中度水华, 而细胞密度大于 $20 \times 10^{6} \mathrm{cells} / \mathrm{L}$ 时则为重度水华 ${ }^{[20]}$. 从沙河水库的多年监测来看, 这一定义对于蓝藻未必合适, 但对硅藻来说是合适的.按照这一定义, 太湖流域 水库硅藻水华形成时, 典型的特征是水色呈棕褐色, 没有明显的表层藻类聚集现象, 但水体透明度显著下降. 当硅藻细胞数达到水华级别时, 水体透明度一般接近或者小于 $1 \mathrm{~m}$.

从 2009-2014 年沙河水库坝前取水口水域水体透明度及 Chl.a 浓度的变化可以看出, 除 2013 年外, 每 年的 5-6 月份坝前水体 Chl.a 浓度都有一个明显的峰值,一般都在 $30 \mu \mathrm{g} / \mathrm{L}$ 以上. 伴随着 Chl.a 浓度峰值的 来临, 水体透明度下降, 特别是 2009、2010、2012 年的水华比较严重, 透明度较低, Chl.a 浓度峰值接近或超过 $40 \mu \mathrm{g} / \mathrm{L}$ 时, 坝前取水口水体透明度则均低于 $1 \mathrm{~m}$ (图 2).

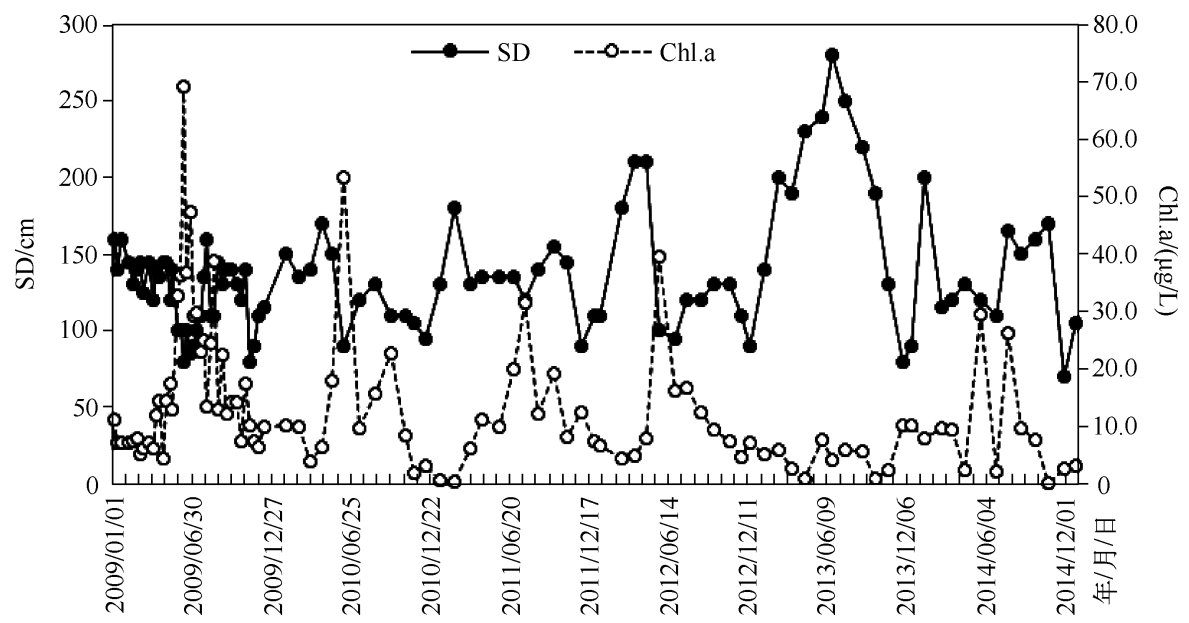

图 2 2009-2014 年沙河水库坝前区透明度及叶绿素 a 浓度的变化

Fig.2 Variation of secchi depth and chlorophyll-a concentration in site TM1 of Shahe Reservoir during 2009 - 2014

2.1.2 下层水体缺氧及异味产生 当硅藻大量生长, 特别是形成水华时, 由于阻挡了光照的穿透深度, 透明度 降至 $1 \mathrm{~m}$ 左右, 相应地真光层深度 (光强衰减到水面光强的 $1 \%$ 以下) 降低到 $2.5 \mathrm{~m}$ 左右.在这种情况下,水下 $3 \mathrm{~m}$ 基本就不适合藻类生长.此时大量积累的生物体会逐渐腐烂分解,特别是湖下层区域.此时如遇交换缓 慢、静风高温的环境条件, 湖体将发生较为严重的厌氧状况.

当因硅藻生物量偏大导致透明度降至 $1 \mathrm{~m}$ 左右时, 可能在 $4 \sim 6 \mathrm{~m}$ 深度下形成缺氧层, 威胁供水安全. 比 如 2014 年 6 月的横山水库和 2009 年 6 月的沙河水库 (图 3a、c). 但也可能呈现逐步下降的趋势, 在 $8 \mathrm{~m}$ 以下 形成缺氧层 (DO 浓度小于 $3 \mathrm{mg} / \mathrm{L}$ ) (图 $3 \mathrm{~b}$ ).

\section{2 太湖流域水库硅藻水华的生物学特征}

2.2.1 生物量的季节变化特征 表征水库水体藻类生物量有 2 个指标: 1) 单位水体的细胞数, 即细胞密度 $(\mathrm{cells} / \mathrm{L}) ; 2)$ 根据细胞密度和具体细胞大小而换算出来的生物量 $(\mathrm{mg} / \mathrm{L})$. 从 $2009-2014$ 年沙河水库坝前 监测点细胞密度这个指标看, 蓝藻是绝对优势种 (图 4a). 蓝藻细胞密度始终接近总藻类细胞密度, 6 年 99 次 调查中, 总细胞密度平均值为 $9789 \times 10^{4} \mathrm{cells} / \mathrm{L}$, 蓝藻细胞密度平均值为 $9183 \times 10^{4} \mathrm{cells} / \mathrm{L}$, 而硅藻细胞密度 

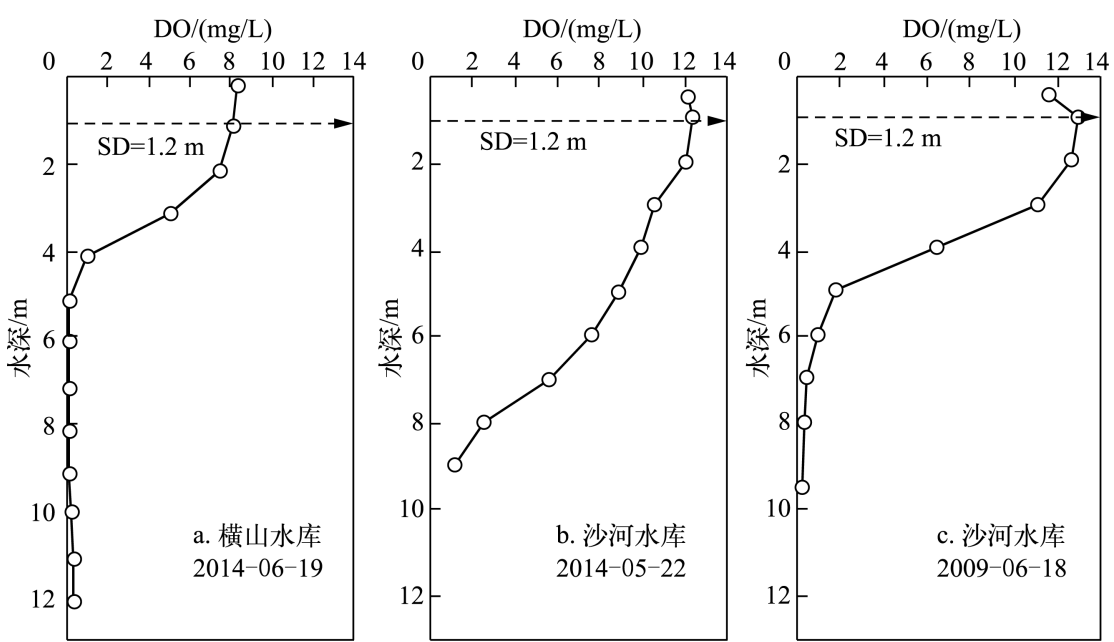

图 3 硅藻水华期 3 次水库坝前溶解氧浓度剖面

Fig.3 DO profiles near the dam during diatom bloom period

平均值为 $345 \times 10^{4}$ cells $/ \mathrm{L}$, 不及蓝藻的 $4 \%$. 就细胞密度的峰值而言, 硅藻一般早于蓝藻 $1 \sim 2$ 个月出现峰值, 大多出现在 5-6月.

然而, 硅藻的细胞密度小并不代表硅藻的生物量小. 蓝藻的细胞个体相对硅藻来说很小, 往往不及硅藻 体型的千分之一. 因此,尽管硅藻细胞密度小, 但是硅藻对于水体浮游植物生物量的总贡献则显著高于蓝藻. 从沙河水库坝前监测点 2009-2014 年浮游植物对应的藻类生物量状况可以看出, 硅藻的生物量贡献明显大 于蓝藻 (图 4b). 6 年来 99 次测定的藻类生物量平均值为 $8.45 \mathrm{mg} / \mathrm{L}$, 其中硅藻生物量平均值为 $3.84 \mathrm{mg} / \mathrm{L}$, 占 总生物量的 $45 \%$, 蓝藻生物量平均值为 $2.00 \mathrm{mg} / \mathrm{L}$, 低于硅藻, 占总生物量的 $24 \%$. 在细胞密度不及蓝藻 $4 \%$ 的情况下, 沙河水库硅藻生物量是蓝藻生物量的近 2 倍 (图 4). 可见, 评估藻类生物量的时候, 仅仅采用细胞 密度这一指标是有偏颇的.

太湖流域水库硅藻水华危害的关键期是 5、6月.图 5 显示了沙河水库坝前 6 年来的年内生物量随时间 的演替过程.一般来说, 硅藻生物量在 4 月开始增加, 5-6 月达到最大, 7 月开始下降, 8 月底之后一般降至 较低水平. 不过, 也有异常早的年份, 比如 2011 年 3 月硅藻生物量就达到了峰值, 但该年因营养盐春季来水 极少, 水体营养盐水平很低, 导致硅藻生长的动力不足, 4 月之后生物量反而下降.2014 年则从 1 月就开始保 持较高水平, 持续时间也比较长, 受 2013 年冬季及 2014 年春季水库底泥疏浚扰动的影响. 底泥疏浚的剧烈 扰动将大量营养盐和硅释放到水体, 使得硅藻生物量持续保持较高水平.

2.2.2 硅藻的种属结构 天目湖沙河水库坝前点位 6 年来硅藻门中共有 9 个属检出, 分别是针杆藻、小环藻、 曲壳藻、直链藻、星杆藻、舟形藻 (Navicula) 、冠盘藻、异极藻 (Gomphonema) 和桥弯藻 (Cymbella). 事实上, 在 常见的淡水水华硅藻属中, 太湖流域的湖库中均检测到, 如小环藻、冠盘藻、直链藻、星杆藻、曲壳藻、针杆藻 等, 都是在我国一些水体报道过引发水华的属. 在沙河水库中, 针杆藻是绝对的硅藻优势属, 多年平均生物量 占硅藻总生物量的 $61 \%$. 基于优势度的计算, 能够列入优势属的还有曲壳藻、小环藻和直链藻, 多年平均生物 量分别占硅藻总生物量的 $17 \% 、 14 \%$ 和 5\% (图 6).

在 2014 年 6 月对宜兴市横山水库的调查中, 发现引发横山水库水色异常的藻类中, 主要也是硅藻中的 针杆藻和蓝藻中的席藻 (Phormidium spp.).6月 15 日的调查发现, 从生物量角度看, 横山水库取水口浮游植 物总生物量为 $19.1 \mathrm{mg} / \mathrm{L}$, 其中硅藻生物量平均值为 $12.8 \mathrm{mg} / \mathrm{L}$, 包括针杆藻生物量为 $12.0 \mathrm{mg} / \mathrm{L}$, 占硅藻生物 量的 $92 \%$; 蓝藻生物量为 $3.6 \mathrm{mg} / \mathrm{L}$, 绝大部分是席藻. 从细胞密度上看, 总细胞密度为 $3.06 \times 10^{8} \mathrm{cells} / \mathrm{L}$, 绝大 多数为蓝藻中的席藻, 蓝藻细胞密度为 $2.97 \times 10^{8} \mathrm{cells} / \mathrm{L}$, 硅藻细胞密度为 $740 \times 10^{4} \mathrm{cells} / \mathrm{L}$. 情况与沙河水库 很相似.

陈开宁等在天目湖大溪水库的多年监测中也发现类似现象. 比如, 从细胞密度上看, 2013 年蓝藻平均细 


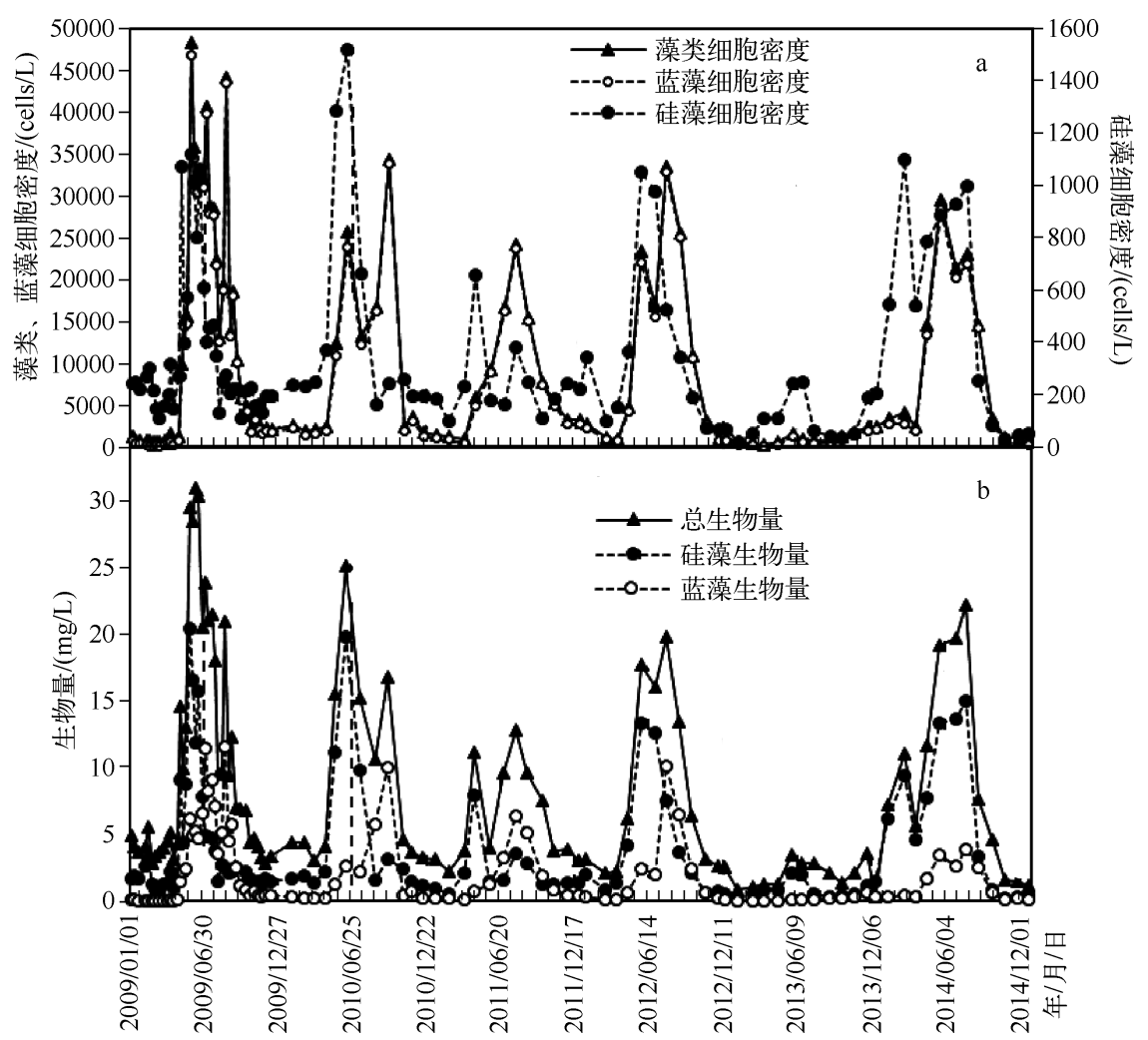

图 4 2009-2014 年沙河水库坝前水域藻类细胞密度及生物量的变化

Fig.4 Cell density and biomass of phytoplankton, cyanobacteria, and diatom near the dam of Shahe Reservoir during 2009-2014

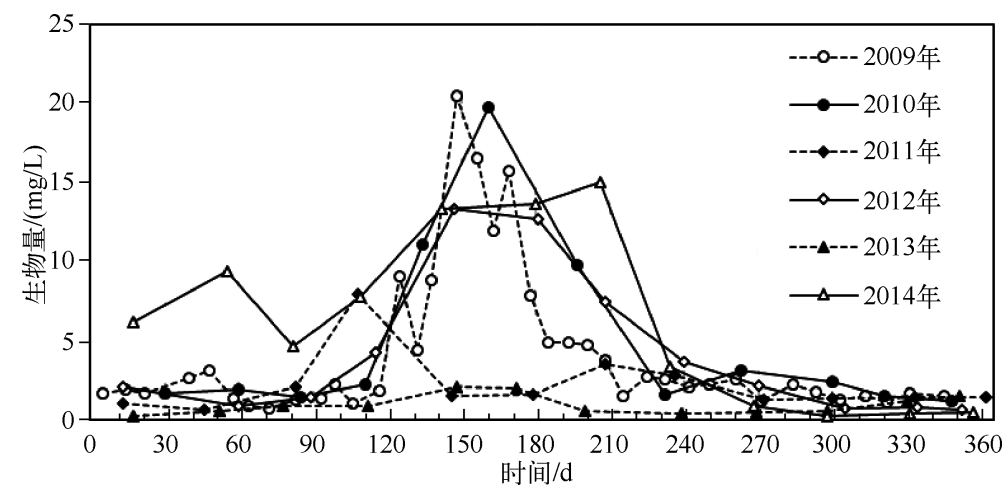

图 5 沙河水库坝前水体硅藻生物量的年变化

Fig. 5 Annual variation of diatom biomass near the dam of Shahe Reservoir

胞密度占总藻类细胞密度的 $77.3 \%, 2014$ 年则占到 $86.3 \%, 2013$ 年硅藻平均细胞密度占总细胞密度的 $9.5 \%$, 2014 年占 $8.6 \%$. 但从生物量方面考虑, 2013 年硅藻生物量占总生物量的 $54.1 \%, 2014$ 年占 $53.8 \%$, 而 2013 年 蓝藻生物量占总藻类生物量的 $10.7 \%, 2014$ 年占 $15.9 \%$ (未发表数据). 硅藻门的优势属种中, 有时针杆藻生 物量最高, 有时颗粒直链藻生物量最高, 这点与沙河水库的情况略有不同. 但是整体上的优势属比较类似, 主 要包括针杆藻、曲壳藻、舟形藻、颗粒直链藻、小环藻、桥弯藻等.

2.2.3 硅藻优势属生物量的季节变化 从 6 年来沙河水库坝前区硅藻 4 个优势种的时间变化可以看出,大多 


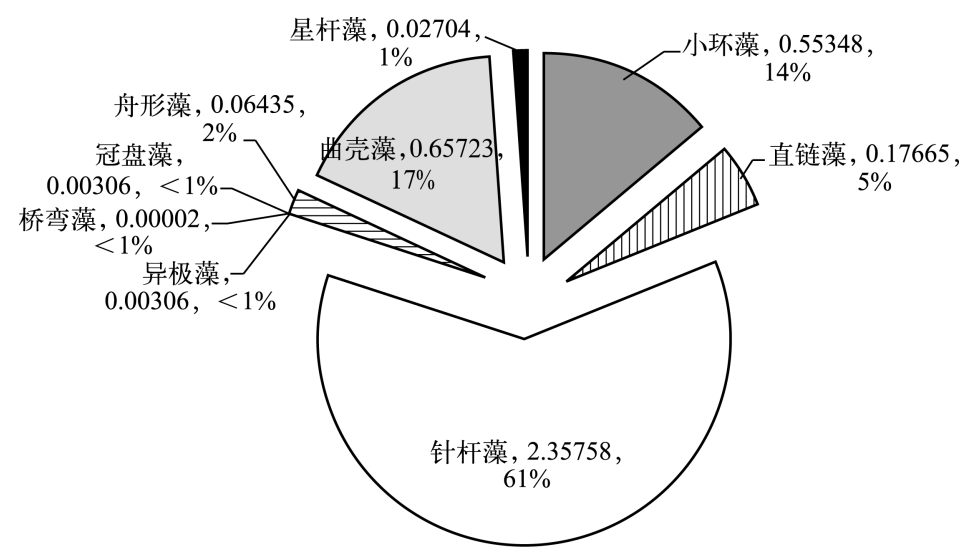

图 $62009-2014$ 年沙河水库坝前水域硅藻群落组成(基于平均生物量, $\mathrm{mg} / \mathrm{L}$ )

Fig. 6 Species composition of diatom near the dam of Shahe Reservoir based on biomass during 2009 - 2014

时候, 各优势属硅藻的年生长峰值都比较锐利, 表明其峰值持续时间较短 (图 7). 从总体生物量上看, 针杆藻 对总生物量起到绝对主导的影响, 其次是曲壳藻, 再次是小环藻和直链藻. 对比图 4 可以看出, 针杆藻主导了 总体藻类生物量的季节变化.

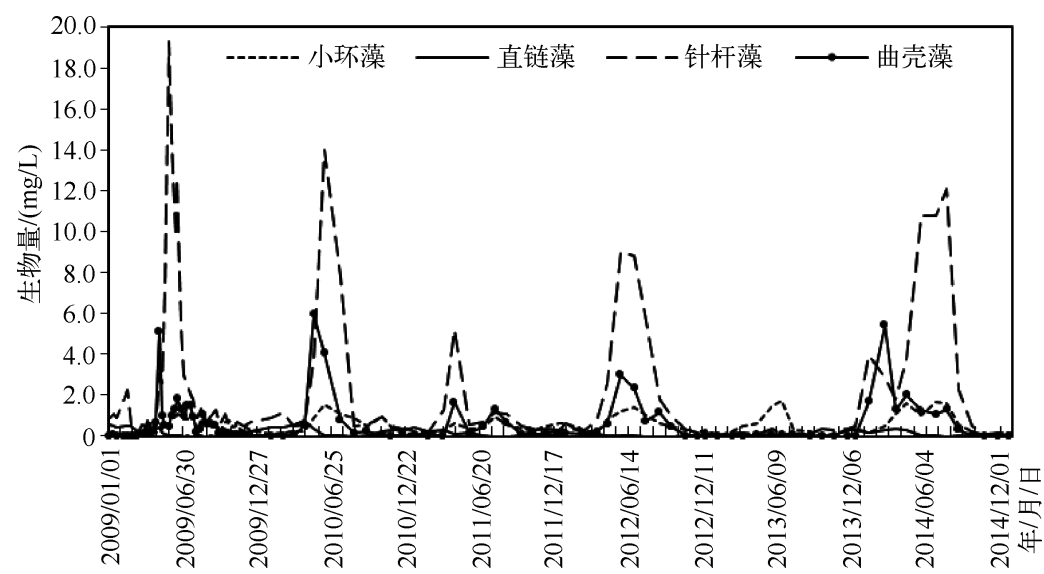

图 7 2009-2014 年沙河水库硅藻 4 个优势属生物量的季节变化

Fig.7 Seasonal variation of biomass of the four dominant genera of diatom in Shahe Reservoir during 2009 - 2014

从一年中硅藻的 4 个优势种生物量的变化情况可以看出, 4 个优势属的最佳生长时间并不完全相同 (图 8 ). 针杆藻的峰值出现在每年的第 130 $212 \mathrm{~d}$ (即 5 月 10 日至 7 月 31 日) 之间, 春末夏初期间, 峰值大致在 第 $151 \mathrm{~d}$ (即 5 月 31 日前后).

曲壳藻的生长时间相对宽泛, 约为第 100 275 d 呈现一个相对平坦的峰值, 即每年的 4 月 10 日-10 月 2 日是曲壳藻的生长旺季. 其中 4 月底至 6 月初往往形成相对更高的生物量.此外, 2014 年冬季开始, 曲壳藻就保 持了较高的生物量,这与当时开展的水库底泥疏浚有关, 说明曲壳澡可能对水体硅的增加更加敏感.

小环藻的生长期相对更加宽泛.从第 70 340 d 小环藻都处于相对高的生长期.也就是除了冬季之外,小 环藻都可能异常增殖.这与小环藻比较普遍的水华物质现象相吻合.总体上看, 在生长期, 小环藻还分成两个 明显的峰,一个峰值出现在第 $180 \mathrm{~d}$ 左右, 也就是在 6 月底的时候, 另外 1 个峰值出现在第 $300 \mathrm{~d}$ 左右, 也就 是 10 月底前后. 而两峰之间的谷值出现在第 $250 \mathrm{~d}$ 左右, 大约是 9 月初.

直链藻则明显属于冬季种, 在第 $16 \sim 290 \mathrm{~d}$ 期间 (即从 6 月初夏季来临, 直到 10 月中旬) 处于低生长期, 
直链藻的生长速率很低. 而在冬、春季节生长速率相对较高.

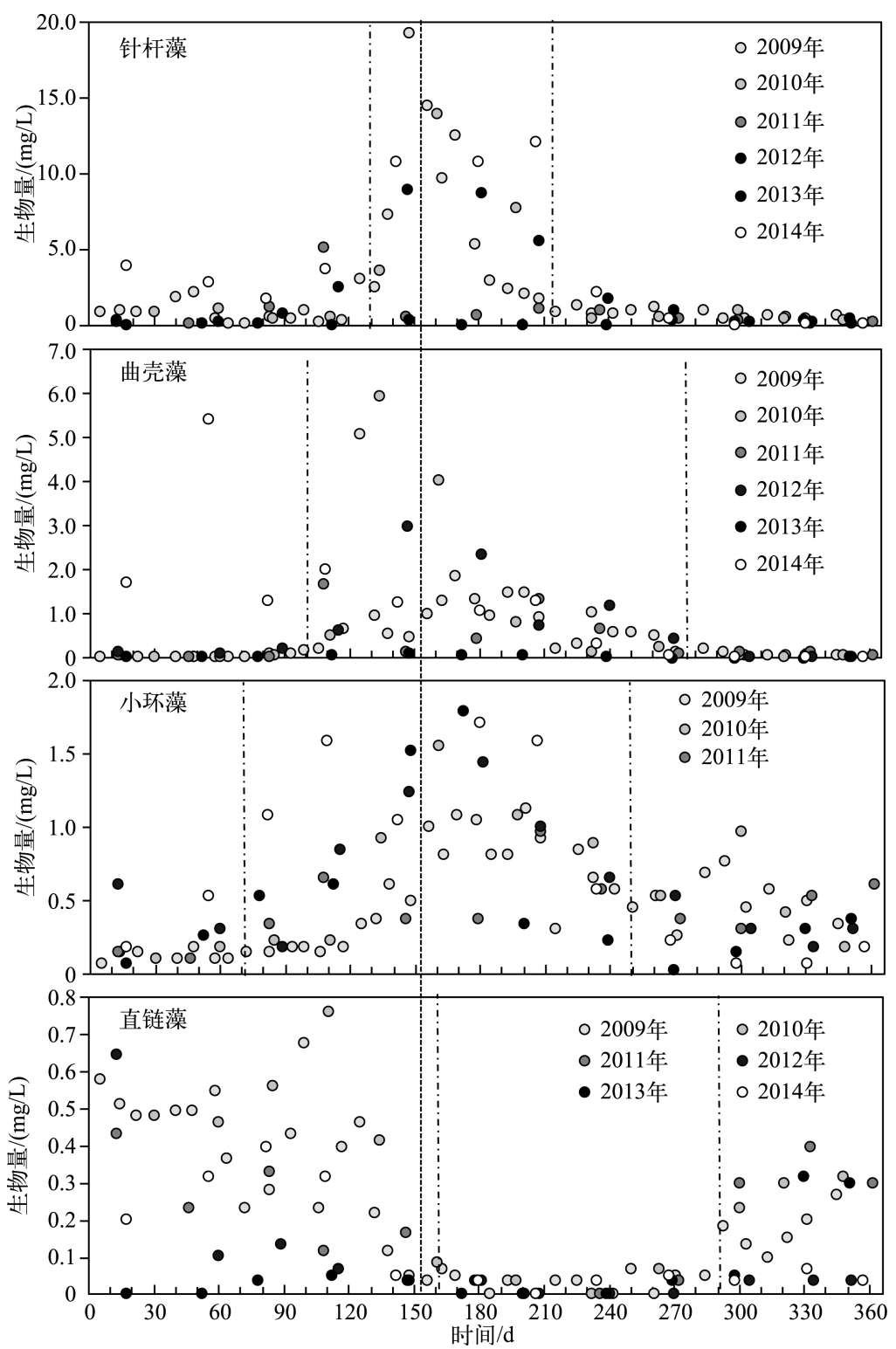

图 8 沙河水库坝前区硅藻优势属的生长期特征

Fig. 8 Seasonal variation of biomass of the dominant genera of diatom near the dam of Shahe Reservoir

\section{3 讨论}

\section{1 温度对硅藻生长的影响}

作为水体中最重要的初级生产者, 温度、光照等光合作用基本条件无疑对硅藻的生长起着极其重要的 作用 ${ }^{[4]}$. 从图 8 也可以看出, 硅藻各优势属的生长具有极强的季节性. 因此, 气温的波动对硅藻生物量影响很 大.从天目湖沙河水库坝前监测点 3 个典型水华年硅藻生物量与气温的关系 (图 9) 可以看出, 总体上硅藻水 华出现的最佳气温是 $16 \sim 26^{\circ} \mathrm{C}$ 之间.一般当气温俳徊在 $16^{\circ} \mathrm{C}$ 以上时, 硅藻生物量开始快速增加. 当气温达到 $26^{\circ} \mathrm{C}$ 左右时, 生物量达到最大. 这一现象与张运林等 2001-2002 年观测时发现的 5、7 月的藻类生物量峰值 
情况相同 ${ }^{[8]}$. 而比龙胜兴等调查发现的乌江水库华丽星杆藻的暴发季节有所滞后 ${ }^{[2]}$. 当气温达到 $26^{\circ} \mathrm{C}$ 以上 时,硅藻生物量则开始下降.2012 年春季温度升高得早,硅藻生物量开始增加的日期也相应变早.而该年高温 来得相对晚,因此硅藻峰值持续的时间也长. 由此看出气温,特别是暖春对于硅藻水华的巨大影响.
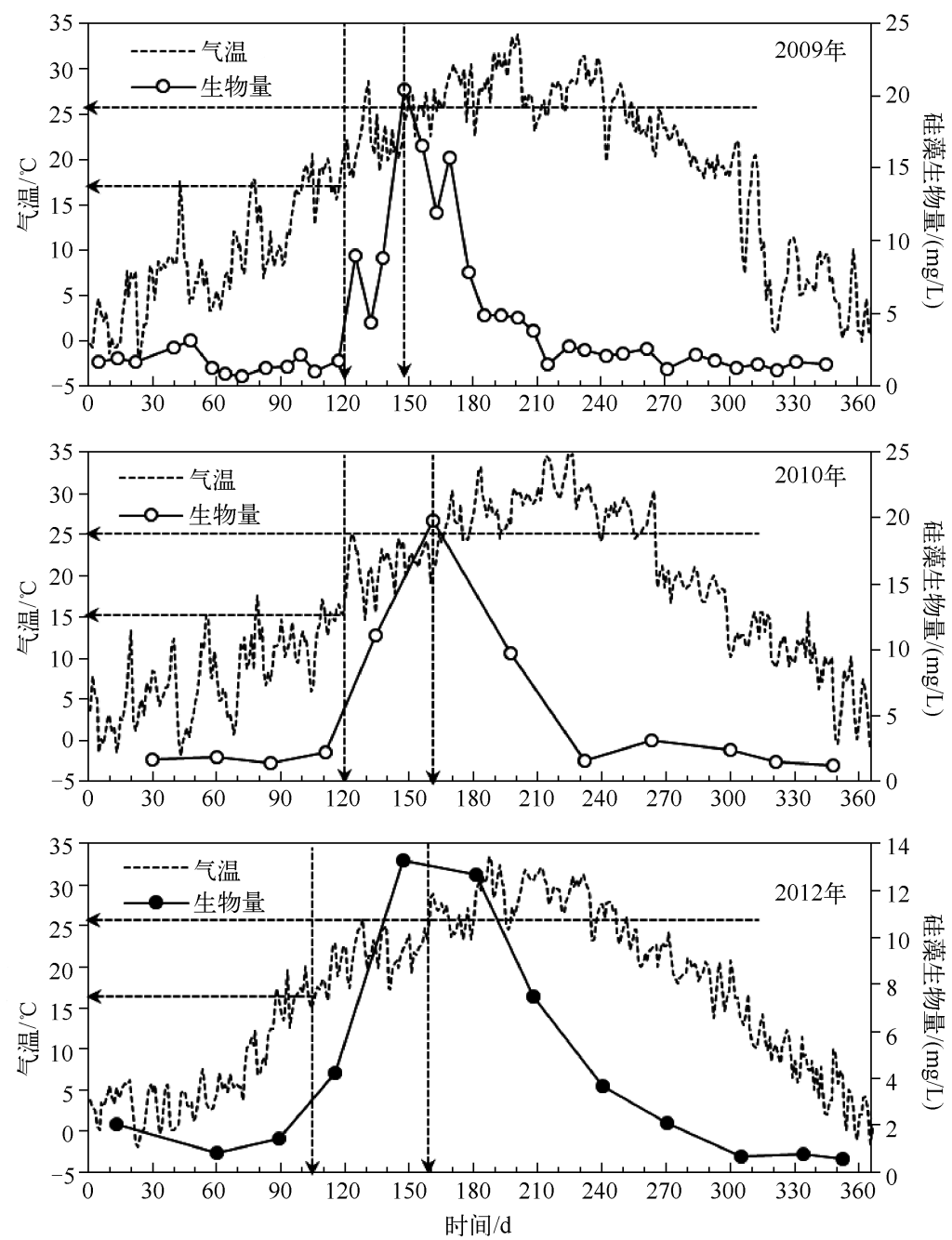

图 9 沙河水库 2009、2010、2012 年气温与硅藻生物量的关系

Fig.9 The relationship between air temperature and diatom biomass in Shahe Reservoir in 2009, 2010 and 2012

从硅藻优势属的季节生长特征可以看出, 硅藻中针杆藻、小环藻、曲壳藻和直链藻 4 个优势属生长的温 度环境并不一致. 由于针杆藻对硅藻生物量的巨大贡献, 图 9 更多地反映了针杆藻的温度生长特征. 最佳生 长温度处于 $16 \sim 26^{\circ} \mathrm{C}$ 之间的主要是针杆藻. 对于小环藻和曲壳藻, 生长的最佳温度更高, 总体上随着温度升 高生物量增加. 而对于直链藻而言, 显然在低温下更适宜生长, 温度超过 $16^{\circ} \mathrm{C}$ 以后生物量下降明显, $26^{\circ} \mathrm{C}$ 以 后生物量处于较低水平.

温度伴随的水体缺氧环境也是硅藻水华腐烂产生异味物质并威胁供水安全的原因.一般持续 $5 \mathrm{~d}$ 以上 的高温戻氧环境对供水而言就非常危险了,可能产生较高浓度的异味物质,如土臭素、2-甲基异茨醇 (2-MIB) 等 ${ }^{[21]}$. 沙河水库 2005 年就因硅藻水华问题,影响了供水水质.经检测, 自来水异味出现期间, 沙河水 库水源地水体 2-MIB 超标 5 10 倍. 由于该水质异味事件的发生, 促使溧阳市政府成立天目湖水源地生态环 境保护领导小组,实施了包括底泥疏浚和河口湿地构建等一系列生态保护工程措施 ${ }^{[16]}$. 


\section{2 降雨和水位对硅藻生长的可能影响}

降雨和水位对硅藻水华的潜在影响有 3 个方面: 1 ) 影响换水周期,从而影响藻类生物量积累过程,降雨 量越大, 水库水力停留时间越短, 水库中藻类生物量的积累程度可能就越低;2) 影响外源营养盐的补给和内 源营养盐的补给, 对于水力停留时间相对较短的水库而言, 水体氮、磷等营养盐水平与外源输人量具有较好 的关系, 根据流域河道水质状况、植被及水土保持能力、降雨的季节情况等, 外源营养盐人库量会有很大变 化. 比如春季农耕季节降雨量大一般意味着更高的外源负荷, 而夏季暴雨则可能降低水体氮、磷负荷. 此外, 水位高低影响湖泊内源释放强度: 水深越大, 夏季水体温度分层越稳定, 内源释放对上层水体藻类生长层的 影响就越小;3) 影响适宜硅藻生长的水温层厚度: 相比常见的有害蓝藻, 硅藻属于相对喜凉的生物, 水位高、 水量大、水温相对较低的环境有利于硅藻在竞争中占优势.而一般浅水、热容低.温度升高快或者昼夜变化大 的水体, 相对更利于蓝藻发挥竞争优势. 由于水位、降雨对硅藻生长的影响是多方面的,因此其关系也是复杂 的,很难给出简单的结论,要具体问题具体分析,但总体而言,水位越低,生态系统越脆弱 ${ }^{[22]}$.

从沙河水库 2009-2014 年 6 年来水库日水位与硅藻生物量、针杆藻生物量之间的关系 (图 10) 可以看 出, 水位和硅藻生物量之间没有直接的关系: 既有低水位、高生物量的情况 (如 2009 年), 也有低水位、低生 物量的情况 (如 2011 年), 还有高水位、高生物量的情况 (如 2010、2014 年), 以及高水位、低生物量的情况 (如 2013 年).这些状况说明, 水位高低本身对于硅藻生物量或者硅藻水华发生并不重要, 重要的是当时的 营养盐、温度状况等其他因子.

从图 10 可以得出初步结论: 冬季持续整个春季的大旱可能意味着春季硅藻低生物量的出现, 如 2011 年 和 2013 年. 2011 年的旱情从 2010 年 8 月就已开始,持续到 6 月初的大旱, 造成了水体营养盐浓度持续下降, 特别是总氮浓度持续维持在较低水平 (低于 $0.8 \mathrm{mg} / \mathrm{L}$ ), 使得整个春季硅藻生物量维持在较低水平, 该年水 质较好. 而 2013 年春季持续维持高水位, 但来水补给较少, 库容较大, 外源营养盐对水库水质的影响小, 也引 起了长时间的清水期. 该年无论总氮浓度还是总体浮游植物生物量都始终处于较低水平. 因此,春季来水少、 营养盐浓度低、硅藻生物量低的原因可能是水库氮补给主要靠春季施肥期的面源污染人库获得. $3-5$ 月是 太湖流域面源氮污染的主要产生期,较少的降雨产流意味着较低的氮污染. 而 2011 和 2013 年水体氮水平可 能均已低于明显限制硅藻生长的水平.

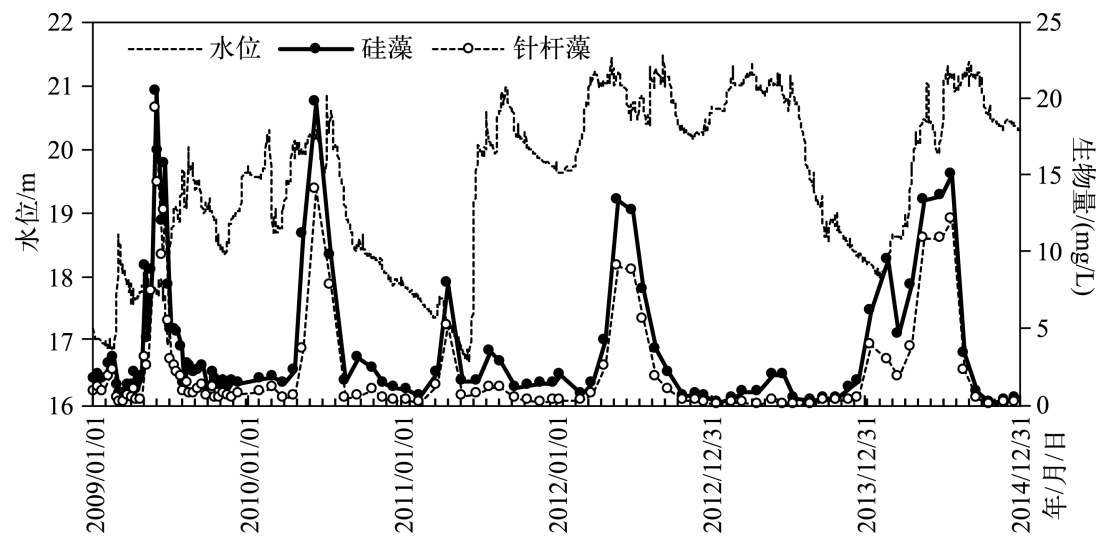

图 10 沙河水库水位与硅藻生物量及优势属针杆藻生物量的关系

Fig.10 Relationships between water level and the biomass of diatom and Synedra in Shahe Reservoir

\section{3 氮、磷营养盐对硅藻的可能影响}

营养盐是浮游植物等初级生产者生物量积累的另外一个重要条件.尽管营养盐的影响没有气温、光照等 重要, 但是改变营养盐是水库生态保护管理中能够实施的最可行的环境条件控制手段, 也是流域人类活动 与水库水华之间最紧密的联系. 因此, 改变营养盐条件成为控制水库硅藻水华最可行的途径.

2009-2014 年以来沙河水库硅藻生物量与全湖总氮浓度之间有较为一致的变化趋势, 随着总氮浓度的 逐年下降, 硅藻生物量总体呈下降的趋势, 除了 2014 年的情况比较特殊. 2014 年是在总氮浓度下降的情况 
下, 硅藻生物量突然升高 (图 11). 从当年的水库管理过程分析, 其原因与 2013 年 11 月开始的水库底泥疏浚 有关. 总的来说, 硅藻生物量与总氮浓度之间有一定的关系 $(P=0.118)$, 但不是特别严密. 需要说明的是, 硅 藻生物量在 2011 年上半年呈现极低值, 当时恰处于总氮浓度低于 $0.8 \mathrm{mg} / \mathrm{L}$, 属于 III 类水, 似乎显示出对硅藻 生长的限制. 也就是说, 在总氮浓度处于 $I V$ 类水以上水平, 即 $>1.0 \mathrm{mg} / \mathrm{L}$ 时, 总氮浓度与硅藻的关系不显著 $(P=$ 0.112 ). 在沙河水库的硅藻生物量水平下 (硅藻生物量 $<25 \mathrm{mg} / \mathrm{L}$ ), 硅藻的生长可能没有受到氮营养盐的 限制.

沙河水库水体总磷浓度的变化趋势并不明显, 硅藻生物量与总磷浓度大致呈一致性, 但不是很显著, 相 关系数 $P$ 仅为 0.02 . 如 2014 年总磷浓度降低至 $0.025 \mathrm{mg} / \mathrm{L}$ 以下时, 硅藻生物量很低, 但在总磷处于 III 类水 及其以上时, 硅藻与总磷浓度的关系不大 (图 11). 相应的统计分析也表明二者相关性不显著 ${ }^{[14]}$. 也就是说, 当总磷浓度在 III 类水水平以上时 (总磷浓度 $>0.025 \mathrm{mg} / \mathrm{L}$ ), 沙河水库水体硅藻生物量条件下 ( 硅藻生物量 $<$ $25 \mathrm{mg} / \mathrm{L}$ ), 硅藻的生长没有受到磷供给的限制.

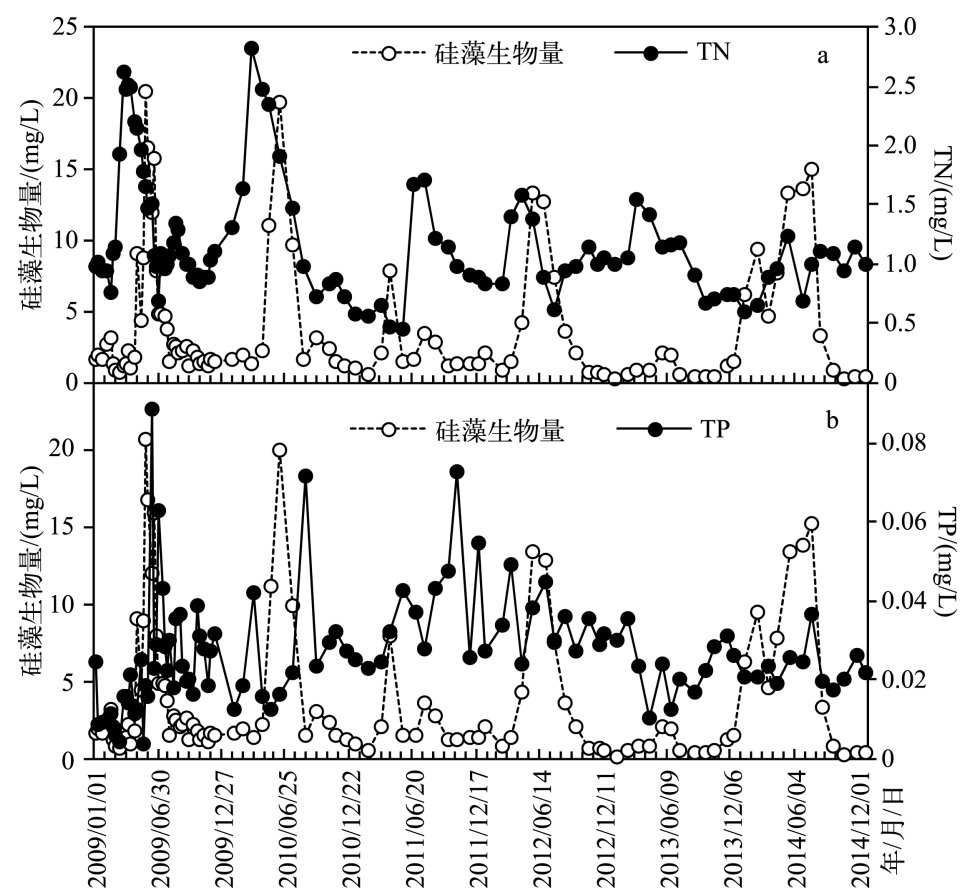

图 $112009-2014$ 年沙河水库水体总氮、总磷浓度与硅藻生物量的关系

Fig.11 Relationships between diatom biomass and total nitrogen

and total phosphorus concentrations in Shahe Reservoir during 2009-2014

从沙河水库的数据分析可以推断, 对于生物量 $<25 \mathrm{mg} / \mathrm{L}$ 的硅藻生长而言, 若要营养盐限制硅藻的生长, 总氮浓度需要控制到 III 类水水平 $(<1.0 \mathrm{mg} / \mathrm{L})$, 总磷浓度需要控制到 II 类水水平 $(<0.025 \mathrm{mg} / \mathrm{L})$. 在这样的 营养水平以上,春末硅藻生物量的高低更多地受到气候、水文条件的控制.

目前太湖流域大多数水库的总氮水平介于 III 类水与 $\mathrm{IV}$ 类水, 有些季节可达 $\mathrm{V}$ 类水甚至劣 $\mathrm{V}$ 类, 而总磷 也大多介于 II 类水与 III 类水之间, 这都处于不限制硅藻生长的临界区, 因此这些水库的硅藻水华风险都存 在. 由于水库的换水周期短, 水库氮、磷浓度很大程度上受当年降雨、面源污染状况的影响, 因此水库硅藻水 华的风险更多地受不同年份气候的差异控制, 具有较大的风险. 而从保护的角度, 流域面源污染的控制, 特别 是氮、磷拦截能力的提升成为降低硅藻水华风险的关键技术途径.

\section{4 太湖流域水库中控制硅藻水华的策略分析}

从上述典型水库硅藻水华的监测和研究可以看出, 太湖流域水库型水源地硅藻水华的优势属是针杆 
藻、小环藻、曲壳藻、直链藻等常见水华属, 其关键危害属是针杆藻. 针杆藻峰值出现在春末夏初的 $5-7$ 月, 生长温度在 $16 \sim 26^{\circ} \mathrm{C}$ 之间容易大量增殖, 细胞密度超过 $1000 \times 10^{4} \mathrm{cells} / \mathrm{L}$, 生物量超过 $15 \mathrm{mg} / \mathrm{L}$, 有时超过 $30 \mathrm{mg} / \mathrm{L}$, 达到水华水平, 大大影响水体透明度和水色的观赏价值.一旦水华持续时间较长, 容易形成下层水 体缺氧,产生 2-MIB、土臭素等还原性异味物质,对水厂的安全供水构成威胁.

从目前太湖流域水库型水源地的水质背景看, 大多数水库处于中营养到中富营养状态, 水体总氮浓度 在春季、春末夏初往往可达 $\mathrm{IV}$ 类水甚至 $\mathrm{V}$ 类水水平, 水体总磷浓度在一些月份也可达到 III 类甚至 $\mathrm{I}$ 类水水 平, 春末夏初既是营养盐的高峰值 ${ }^{[23]}$, 又恰恰是硅藻异常增殖的最佳时期, 二者的结合很容易形成 $1 \sim 2$ 个 月的硅藻水华期.

从硅藻优势种生长的环境条件分析看, 气温、降雨过程等对硅藻水华的形成具有很大的影响, 然而这是 基于营养盐水平足够高的基础之上的.从沙河水库 6 年的逐月观测结果看, 当水体总氮浓度 $<1.0 \mathrm{mg} / \mathrm{L}$ 时,或 者水体总磷浓度 $<0.025 \mathrm{mg} / \mathrm{L}$ 时, 即便遇到同样温暖的气候, 硅藻异常增殖、形成水华的过程也可能会得到 遏制.气候是不可控的环境条件, 从管理者的角度考虑, 降低硅藻水华风险, 目前所能做的主要是营养盐削减 的上行效应策略以及鱼类调控的下行效应策略 2 个途径.

我国水库普遍实施鱼类养殖.中国科学院水生生物研究所的谢平教授还提出利用鲢、鲜鱼控制蓝藻水华 的理论 ${ }^{[24]}$. 然而, 该理论是基于蓝藻水华生物量很高的前提下实施的一种途径. 对绝大多数中营养、中富营 养的水库并不适用. 原因是水库大多是分层的, 水体藻类残体往往沉到底层, 长时间之后慢慢分解释放, 重新 把营养盐释放回水体. 而鱼类的大量牧食、排泄将大大加快营养盐在湖上层水体中的循环, 反而刺激藻类的 快速生长. 同时, 鲢、鳙等滤食性动物对水体浮游动物和浮游植物同时产生压力, 鲢的食物中浮游动物可以占 到 $40 \%$, 浮游植物占 $60 \%$, 而鳙的食物中浮游动物甚至占 $60 \%{ }^{[24]}$. 鱼滤食浮游植物的同时, 也大大降低了经 典食物链中对浮游植物生物量控制最为有效的浮游动物对浮游植物的控制能力.

正因如此,鲢、鳙鱼控制蓝藻水华的理论目前仅仅在重富营养的浅水湖泊蓝藻水华问题上认可度较高, 在中营养水体的争议较大, 在硅藻水华上的争议也很大. 比如韩国在 $1980 \mathrm{~s}$ 初在水库中引人了渔业养殖, 对 水库水质产生了较大的影响, 水库的水质保护部门、研究单位历经 10 年的不解努力, 才在 1997 年韩国立法 取缔所有水库的渔业养殖,水库水质得到明显的改善 ${ }^{[25]}$. 此外,在匈牙利的巴拉顿湖 $1970 \mathrm{~s}$ 也曾发生过蓝藻 水华, 当时的管理者引人了鲢、鳙鱼加以控制, 反而引起了更大的灾害, 水质更加恶化.之后匈牙利科学家经 过大量研究,说服管理者,清除滤食性鱼类, 同时实施严格的营养盐控制, 目前巴拉顿湖的水质已经恢复到 良好状态.

沙河水库自 2005 年发生自来水异味事件以来, 加大了对养殖渔业的调控. 其中主要的措施是控制总体 渔业规模, 湖体渔业现存量控制在 $2 \sim 5 \mathrm{~g} / \mathrm{m}^{3}$ 以下, 同时大大提高鲢、鳙比例, 投放鱼苗中鲢鱼比例控制在 $80 \%$ 以上,经过近 10 年的实践, 总体效果还不错.在经营性渔业不能完全清理的情况下,也不失为一个权宜 之计.

控制硅藻水华最根本的途径仍是营养盐削减控制策略.特别是对中营养水体, 营养盐限制的作用开始显 现, 此时在营养盐控制方面的努力将起到事半功倍的效果, 也是治本之策.从天目湖的治理经验看, 将水库总 磷浓度稳定控制在II类水水平 (即全年 $<0.025 \mathrm{mg} / \mathrm{L}$ ) , 总氮浓度稳定控制在 III类水 (即全年全部 $<1.0 \mathrm{mg} / \mathrm{L}$ ), 将 硅藻水华风险控制在较低的水平.

从太湖流域水库水质现状看, 磷往往更接近控制目标, 因此容易忽略对氮的控制.但是从沙河水库 6 年 来的控制效果看, 磷的浓度水平尽管总体不高,但是流域治理措施之后对磷的控制效果并不理想,也就是进 一步降低磷浓度的难度很大. 而氮虽然背景情况比较高, 但是氮的截留、降解的效果相对更好. 因此氮的控制 不能放弃. 应当采取氮、磷同时控制的策略. 特别是针对农业开发比例较大的水库, 氮的控制更需加强. 近年 来在天目湖实施的一系列流域营养盐削减工程, 包括控制流域开发比例, 在临湖面、滨湖带设置缓冲区, 构 建河口湿地及流域各类湿地, 以及设置农业、茶果园土地缓冲带和控制施肥量, 取得了比较好的效果 ${ }^{[16]}$.

\section{4 结论}

太湖流域地处我国东南湿润区的丘陵山区, 气候温暖湿润, 藻类生长期长, 降雨充沛, 营养盐补充途径 
多. 加之该流域人口密集, 开发强度高, 大多数水库的硅藻、蓝藻水华发生风险较高. 基于沙河水库的多年观 测分析, 太湖流域水库硅藻水华的高发期是春末夏初 (即 5-7 月), 略早于蓝藻水华, 发生水华的主要优势 属是针杆藻属、小环藻属、曲壳藻属和直链藻属, 其中关键危害属为针杆藻属.

太湖流域水库中硅藻的生长受气温、气候、降雨的影响很大, 同时也受氮、磷、硅等营养盐供给的影响.温 暖、湿润的春季气候有利于硅藻水华的发生. 在总氮浓度 $>1.0 \mathrm{mg} / \mathrm{L}$ 、总磷浓度 $>0.025 \mathrm{mg} / \mathrm{L}$ 的营养盐条件下, 营养盐对硅藻水华的影响小于气候因素. 而当氮、磷低于上述阈值时, 则可能对硅藻水华的严重程度产生明 显抑制作用.

在防控对策上, 营养盐削减仍是最可行的控制途径. 外源营养盐削减途径中, 降低流域开发比例最为重 要, 此外, 临湖面、滨湖带缓冲区建设, 河口湿地和各类湿地的恢复, 以及农业、茶果园土地缓冲带的设置和 施肥量控制, 都是比较可行的外源控制途径. 而库体调控手段中, 底泥疏浚、控制经营性鱼类库存量、恢复野 杂鱼等措施是比较可行的营养盐削减和生物量调控手段.

致谢: 藻类鉴定工作由周万平完成, 大溪水库 2013-2014 年藻类状况数据由陈开宁研究员提供, 部分样品采 集由韩晓霞硕士生、崔扬硕士生、夏忠工程师完成, 沙河水库管理处高志勤工程师提供了部分气象数据, 溧 阳市天目湖水源地生态环境保护领导小组办公室提供了常规监测的经费, 在此一并表示感谢.

\section{5 参考文献}

[ 1 ] 董君卿. 浅析横山水库硅藻“水华”发生、预防、治理. 经济师, 2011, (10) : 289-290.

[2] 龙胜兴, 陈 椽. 乌江上游筑坝蓄水后各水库浮游硅藻及浮游动物群落生态特征. 贵州师范大学学报: 自然科学 版, 2009, 27(3): 21-26.

[ 3 ] 林 昱, 林荣澄. 厦门西港引发有害硅藻水华磷的阈值研究. 海洋与湖沼, 1999, 30(4) : 391-396.

[ 4 ] 杨 强, 谢 平, 徐 军等. 河流型硅藻水华研究进展. 长江流域资源与环境, 2011, 20(Z1)：159-165.

[ 5 ] 王 敏, 张 智, 郭蔚华等. 嘉陵江出口段硅藻水华发生规律. 环境科学研究, 2011, 24(2): 191-198.

[6 ] 梁开学, 王晓燕, 张德兵等. 汉江中下游硅藻水华形成条件及其防治对策. 环境科学与技术, 35(12J)：113-116.

[ 7 ] 李秋华, 韩博平. 基于 CCA 的典型调水水库浮游植物群落动态特征分析. 生态学报, 2007, 27(6): 2355-2364.

[ 8 ] 张运林, 陈伟民, 周万平等. 2001-2002 年天目湖 (沙河水库) 浮游植物的生态学研究. 海洋湖沼通报, 2006, (2) : 31-37.

[ 9 ] 辛晓云. 河南南湾水库浮游硅藻的种群结构与水质污染评价初步研究. 生态学杂志, 2003, 22(5): 125-126.

[10] 郑凌凌, 宋立荣, 吴兴华等. 汉江硅藻水华优势种的形态及 $18 \mathrm{SrDNA}$ 序列分析. 水生生物学报, $2009, \mathbf{3 3}(3)$ : $562-565$.

[11] 王翠红, 张金屯. 汾河水库及河道中优势硅藻生态位的研究. 生态学研究, 2004, 23(3) : 58-62.

[12] 韩博平. 中国水库生态学研究的回顾与展望. 湖泊科学, 2010, 22(2) : 151-160. DOI 10. 18307/2010. 0201.

[13] 胡尊乐, 潘 杰. 溧阳市饮用水源地安全评价研究. 江苏水利, 2011, (3) : 44-45.

[14] Zhu G, Cui Y, Han X et al. Response of phytoplankton to nutrient reduction in Shahe Reservoir, Taihu catchment, China. Journal of Freshwater Ecology, 2015, 30: 41-58. DOI: 10. 1080/02705060. 2014. 994190.

[15] 贺冉再, 高永霞, 王 芳等. 天目湖水体与沉积物中营养盐时空分布及成因. 农业环境科学学报, 2009, 28(2): 353-360.

[16] 李恒鹏, 朱广伟, 陈伟民等. 中国东南丘陵山区水质良好水库现状与天目湖保护实践. 湖泊科学, 2013, 25(6): 775-784. DOI 10. 18307/2013. 0601.

[17] 万亚芹, 韩 蒙, 李兆富. 2000 年以来天目湖流域茶园分布变化及趋势模拟. 湖泊科学, 2013, 25(6): 799-808. DOI 10. 18307/2013. 0603.

[18] 崔 扬, 朱广伟, 李慧贽等. 天目湖沙河水库水质时空分布特征及其与浮游植物群落的关系. 水生态学杂志, 2014, 35(3): 10-18.

[19] 章宗涉, 黄祥飞. 淡水浮游生物研究方法. 北京: 科学出版社, 1991.

[20] 郑建军, 钟成华, 邓春光. 试论水华的定义. 水资源保护, 2006, 22(5) : 45-47, 80.

[21] Parinet J, Rodriguez MJ, Serodes J. Influence of water quality on the presence of off-flavour compounds (geosmin and 2methylisoborneol). Water Research, 2010, 44: 5847-5856. 
[22] 朱广伟, 赵林林, 陈伟民等. 低水位运行对天目湖水库水质与生态的影响. 生态与农村环境学报, 2011, 27(4): 87-94.

[23] 朱广伟, 李恒鹏, 陈伟民等. 天目湖沙河水库水质对流域开发与保护的响应. 湖泊科学, 2013, 25(6): 809-817. DOI 10. 18307/2013. 0604.

[24] 谢 平. 鲢、鳙鱼与藻类水华控制. 北京: 科学出版社, 2003.

[25] Kim B, Park JH, Hwang J et al. Eutrophication of reservoirs in South Korea. Limnology, 2001, 2(3) : 223-229. 